\title{
Contribution of soil moisture feedback to hydroclimatic variability
}

\author{
N. Y. Krakauer ${ }^{1}$, B. I. Cook ${ }^{2}$, and M. J. Puma ${ }^{2}$ \\ ${ }^{1}$ Department of Civil Engineering, The City College of New York, New York, USA \\ ${ }^{2}$ NASA Goddard Institute for Space Studies, New York, USA \\ Received: 21 October 2009 - Published in Hydrol. Earth Syst. Sci. Discuss.: 12 November 2009 \\ Revised: 13 February 2010 - Accepted: 2 March 2010 - Published: 15 March 2010
}

\begin{abstract}
While a variety of model experiments and analyses of observations have explored the impact of soil moisture variation on climate, it is not yet clear how large or detectable soil moisture feedback is across spatial and temporal scales. Here, we study the impact of dynamic versus climatological soil moisture in the GISS GCM ModelE (with prescribed sea-surface temperatures) on the variance and on the spatial and temporal correlation scale of hydrologically relevant climate variables (evaporation, precipitation, temperature, cloud cover) over the land surface. We also confirm that synoptic variations in soil moisture have a substantial impact on the mean climate state, because of the nonlinearity of the dependence of evapotranspiration on soil moisture.

We find that including dynamic soil moisture increases the interannual variability of seasonal (summer and fall) and annual temperature, precipitation, and cloudiness. Dynamic soil moisture tends to decrease the correlation length scale of seasonal (warm-season) to annual land temperature fluctuations and increase that of precipitation. Dynamic soil moisture increases the persistence of temperature anomalies from spring to summer and from summer to fall, and makes the correlation between land precipitation and temperature fluctuations substantially more negative. Global observation sets that allow determination of the spacetime correlation of variables such as temperature, precipitation, and cloud cover could provide empirical measures of the strength of soil moisture feedback, given that the feedback strength varies widely among models.
\end{abstract}

\section{Correspondence to: N. Y. Krakauer} (nkrakauer@ccny.cuny.edu)

\section{Introduction}

Climate feedbacks involving land-atmosphere fluxes of water, sensible heat, radiation, and dust have been extensively studied using numerical models and observations. Landsurface fluxes have been implicated as important contributors to extreme climate events including the 1930s North American Dust Bowl (Koven, 2006; Cook et al., 2008, 2009), more recent droughts in the United States (US) (Trenberth and Guillemot, 1996; Hong and Kalnay, 2000), the 2003 European heat wave (Fischer et al., 2007; Zampieri et al., 2009), and, somewhat controversially, desertification in the Sahel (e.g. Charney et al., 1975; Zeng et al., 1999). Because landsurface conditions can have a long "memory", a better understanding of land-surface fluxes would enable improved seasonal prediction of weather and weather-related processes such as reservoir storage, crop growth, and epidemic outbreak. It could also permit better targeting of alterations to the land surface (e.g. forestation of desert boundaries, Liu et al., 2008; Ornstein et al., 2009) to achieve desirable climate consequences.

A simple, and important, climate system feedback involving the land surface acts through evapotranspiration rate (Shukla and Mintz, 1982). (In this paper, we use "evaporation" and "evapotranspiration" interchangably to include both biotic and abiotic processes, unless stated otherwise.) Over most of the land surface, moisture availability at the soil surface and in the root zone limits evapotranspiration at least seasonally. This moisture availability depends on recent precipitation, and, in turn, the evapotranspiration rate affects atmospheric temperature, water vapor content, and local or downwind cloudiness and precipitation. This feedback could have a substantial effect both on mean climate and on the occurrence and persistence of dry or wet spells and thus be important for applications such as seasonal drought prediction. A number of numerical modeling investigations have been undertaken to characterize the strength and effects of this feedback. 
A common general approach to diagnose soil moisture feedback in numerical models has been to evaluate the variability of evaporation, precipitation, and temperature in runs where soil moisture is prescribed as compared to runs where soil moisture is allowed to vary (e.g. Schlosser and Milly, 2002; Koster et al., 2002, 2004; Conil et al., 2007). The time scales of variability examined are typically days to months. The general finding of these modeling investigations has been that soil moisture variability is an important determinant of variability in precipitation and other meteorological variables, but that the degree and geographical distribution of this influence depends on the model used (e.g. Dirmeyer et al., 2006). This dependence is not surprising, because the precipitation of water evaporated from the land surface is represented only crudely in current numerical models of global climate; modeled soil moisture feedback on climate can vary dramatically depending on model resolution and on the parameterization of small-scale convection (Hohenegger et al., 2009). As evidence that soil moisture feedbacks simulated by current models do represent some aspects of actual climate, model synoptic forecasts and seasonal hindcasts have been found to show improved skill when using observation-based as compared to climatological or modelderived soil moisture boundary conditions (e.g. Yang et al., 2004; Conil et al., 2007; Jeong et al., 2008).

Observed correlations between past soil moisture and meteorological variables including precipitation, mean temperature, and diurnal temperature range have also been studied as evidence for soil moisture feedback (e.g. Findell and Eltahir, 1997; Luo et al., 2007; Zhang et al., 2008, 2009). However, correlations that are not local are hard to detect with this approach, and care needs to be exercised not to attribute meteorological persistence to soil moisture feedback when it may in fact have other causes (e.g. Wei et al., 2008).

Several previous studies have used model simulations to quantify the impact of soil moisture feedback on seasonal to interannual climate statistics. Delworth and Manabe (1989) compared the variance and temporal autocorrelation of monthly anomalies in near-surface relative humidity and other meteorological fields in a 50-year atmospheric general circulation model run with interactive soil moisture (using a simple one-layer, bucket representation of soil moisture) as compared to a 25-year run where soil moisture content was prescribed, finding that interactive soil moisture increased substantially the variance and autocorrelation of monthly climate over land, particularly during summer in the northern midlatitudes, as well as the amplitude of low-frequency (seasonal to interannual) humidity fluctutations over temperate North America. Koster and Suarez (1995) compared the variance of annual precipitation in 10-year atmospheric general circulation model runs with dynamic versus fixed landsurface moisture availability (expressed as "evaporative efficiency"), finding that interactive moisture availability substantially increased precipitation variance over most tropical and midlatitude land areas, and that moisture availability variation contributed more than variation in sea surface temperatures to interannual precipitation variance in many midlatitude land regions. Koster et al. (2000) largely reproduced these findings with an ensemble of longer (200-year) runs of a newer version of the general circulation model. Reale and Dirmeyer (2002) and Reale et al. (2002) considered mean climate state and interannual precipitation variance under fixed versus interactive evaporative efficiency in 49-year model runs, finding that interactive moisture availability changes mean climate and circulation patterns and that precipitation variance responds rather nonlinearly to the combined interannual variability of sea surface temperature and soil moisture. Schubert et al. (2004) compared a 100-year model run with interactive soil moisture with one that had fixed landsurface evaporative efficiency, finding that over the Great Plains interactive soil moisture not only greatly increases the interannual variance of evaporation and precipitation but also introduces a positive autocorrelation of annual precipitation that does not exist in the absence of soil moisture feedback, i.e. sequences of consecutive wet or dry years become more common. Schubert et al. (2004) do not discuss the impact of interactive soil moisture on other land regions.

Here, we extend these studies by explicitly examining how soil moisture feedback changes the spatial, as well as temporal, scale of seasonal to annual climate anomalies, across all land regions and seasons. To do this, we calculate measures of correlation length and time scales of evaporation, precipitation, temperature, and cloudiness. This analysis is relevant to questions such as whether soil moisture feedback tends to make droughts longer and bigger in spatial extent, and if so, where this effect is largest. It also contributes to basic understanding of soil moisture feedback in models versus observations and provides new avenues for applications of this understanding to drought prediction and land-surface modification.

\section{Methods}

\subsection{Model simulations}

The modeling experiments were conducted with the Goddard Institute for Space Studies (GISS) ModelE at $2^{\circ}$ latitude by $2.5^{\circ}$ longitude horizontal resolution and with 40 vertical layers (Schmidt et al., 2006). ModelE is a state of the art atmospheric general circulation model, incorporating significant updates to the physics compared to previous versions. Simulations of contemporary climate in ModelE have been found to compare favorably with observations, with some notable biases, particularly in the subtropical marine stratocumulus regions. The GISS model replicates the climate of the 20th Century, including trends and low and high frequency variability, when forced with modern forcings and observed sea surface temperature (SST) (Hansen et al., 2007).

Natural vegetation cover is based on Matthews (1983) and is constant over time. For grid cells with cropland, historical 
crop area is taken from the dataset of Ramankutty and Foley (1999) and is updated every ten years. All of our simulations are forced with interannually varying observed sea surface temperatures from HadISST1 (Rayner et al., 2003).

The land model in ModelE is primarily as described by Rosenzweig and Abramopoulos (1997), with a substantially revised and improved canopy conductance scheme (Friend and Kiang, 2005; Aleinov and Schmidt, 2006). The model computes properties and fluxes for each land grid cell assuming separate bare soil, vegetated area, and lake fractions. There are six soil layers with respective thicknesses of $0.10 \mathrm{~m}, 0.17 \mathrm{~m}, 0.30 \mathrm{~m}, 0.51 \mathrm{~m}, 0.89 \mathrm{~m}$ and $1.53 \mathrm{~m}$, for a total depth of $3.5 \mathrm{~m}$. Five soil textures are distinguished: sand, loam, clay, peat and bedrock. Each layer may contain a mixture of these soil types, and soil hydraulic and thermodynamic properties are computed based on their relative proportions. At each time step, soil moisture and soil temperature are calculated separately for bare soil and vegetated fractions of each grid cell. By default, soil moisture is dynamic, changing as a result of evaporation from the surface, extraction by plant roots, percolation of precipitation, and transport between soil layers. Evaporation from bare soil is a linear function of the water content of the top soil layer (Abramopoulos et al., 1988). Plant transpiration is proportional to a soil water availability scalar, which over the range between the wilting point and field capacity is a (decreasing) linear function of water matric potential but an (increasing) nonlinear function of soil water content (Abramopoulos et al., 1988, Fig. 8).

The GISS ModelE land surface model has been calibrated against measured evaporation fluxes from several FLUXNET sites representing different biomes, which has yielded regionally reduced biases in temperature, cloud cover, and precipitation fields relative to previous versions (Friend and Kiang, 2005). A version of the GISS ModelE that includes water isotope tracers showed good agreement with measured riverine water isotope ratios, suggesting that evaporation and runoff are being represented acceptably on the scale of large river basins (Aleinov and Schmidt, 2006). Compared to observational time series of 20th Century soil moisture, the performance of GISS ModelE was comparable to that of other general circulation models that have contributed to the Fourth Assessment Report of the Intergovernmental Panel on Climate Change: the mean seasonal cycle of soil moisture was generally well represented, but the decadal-scale increase in soil moisture seen at sites in Russia and the Ukraine was not captured, perhaps because the model forcing fields underestimate the magnitude of solar dimming due to aerosol pollution, which has regionally reduced evaporation ( $\mathrm{Li}$ et al., 2007).

The results presented here are from 30-year simulations with the GISS ModelE for 1951-1980. Starting from a generic 20th Century initial condition, the model was integrated for two successive 30-year 1951-1980 periods with the default dynamic soil moisture behavior to ensure that the temperature and moisture content of the lower soil layers were near equilibrium. From a third successive 1951-1980 integration with dynamic soil moisture (DYNA), monthly mean soil moisture for each of the 6 soil levels was then used to construct a soil moisture climatology for each layer and calendar month. We then carried out another integration (CLIM) with the same SST and initial condition as DYNA. The only difference between the CLIM and DYNA integrations was that in CLIM, soil moisture in each soil layer did not evolve dynamically but instead was fixed to the climatology obtained from the DYNA integration (whose monthly mean values were interpolated to a daily timestep with a cubic spline), so that it had the mean spatial and seasonal variability but no synoptic or interannual variability. Thus, soil moisture feedback was effectively turned off in the CLIM integration.

The standard GISS ModelE land surface model, as used in the DYNA integration, conserves water mass, in the sense that the change in water stored in the soil, canopy, and snowpack over any time period is equal to precipitation minus evaporation and runoff (Schmidt et al., 2006). The atmospheric model also conserves water, in that the change in atmospheric water vapor mass is equal to evaporation minus precipitation (Schmidt et al., 2006). In the CLIM integration, the land surface model does not conserve water, because the soil moisture is kept at climatology regardless of how much water percolates, evaporates, or runs off, although the atmospheric model continues to conserve water.

\subsection{Analysis}

We considered the impact of the presence or absence of soil moisture feedback on the following climate fields: (a) evaporation, (b) surface air temperature, (c) precipitation, (d) fractional cloud cover. Together, these fields set the most significant terms of energy and water balance. Evaporation is expected to be most directly associated with local soil moisture levels and thus to be most sensitive to whether soil moisture is dynamic or fixed, while the other fields are strongly affected by large-scale transport as well as local fluxes and thus may be less sensitive.

For each climate field, we examined the difference in annual and seasonal mean values between the runs DYNA and CLIM. While the mean soil moisture at each grid cell and time of year of the two runs was set to be equal, we nevertheless expected that mean climate state could differ substantially between the two runs because of the nonlinear response of evaporation to soil moisture. Where near-surface soil moisture alternates between close to saturation (typically after rain) and much less than saturation, imposing the average soil moisture value will tend to lead to higher average evaporation as compared to allowing realistic soil moisture fluctuations. We did indeed find this sort of response (see below). 
In addition to the mean state, we calculated the interannual variance of annual and seasonal climate for each run. The reduction in interannual variance without soil moisture feedback is an indication of the fraction of variability in seasonal and annual scale climate (for example, pluvials and droughts) contributed by soil moisture feedback.

We wanted to assess the impact of soil moisture feedback not only on the mean and variance of climate, but also on the persistence of anomalous climate in space and time over timescales of seasons to years. For each climate variable and grid cell, we calculated the sample autocorrelation of the 12-month moving average of the variable at a 12-month lag $\left(r_{12}\right)$. Assuming that the lagged autocorrelation decays exponentially with lag, we then defined the correlation timescale (in years) as $\tau_{c}=-1 / \ln \left(r_{12}\right)$ (or 0 if $r_{12} \leq 0$ ). To quantify correlation at seasonal time scales, we also calculated, separately for each season, the sample autocorrelation of the 3month moving average of the variable at a 3-month lag (for example, the 3-month lagged correlation between precipitation in March-April-May and precipitation in June-JulyAugust of the same year). We defined a correlation length scale for a climate variable as the decay length of the spatial correlation of the variable in the east-west direction, estimated by a least-squares fit of an exponential decay function to the spatial correlogram (the sample correlation of the time series of the variable at a particular grid cell with that at other grid cells at the same latitude, as a function of distance between grid cells).

A useful way of thinking about the significance of a difference in a climate field between the CLIM run (with climatological soil moisture) and the DYNA run (with interactive soil moisture) is the chance that a small perturbation in the DYNA run that does not systematically modify the soil moisture feedback will lead to a difference of the same magnitude. The standard deviation across the ensemble of three successive 30-year runs, which share interactive soil moisture and the 1951-1980 sea surface temperature field but have different initial conditions, provided an estimate of the magnitude of this "random" variability. To estimate the statistical significance of differences between CLIM and DYNA, we further assumed that the random variability was normally distributed across model realizations. $p=0.10$ (two-tailed), corresponding to 3.6 standard deviations of the ensemble formed by the DYNA run and the two previous runs, was taken as the threshold for considering a difference between CLIM and DYNA to be a significant impact of soil moisture feedback. (In this method of estimating the significance level of differences between CLIM and DYNA, the across-run variance was estimated from an ensemble of runs with dynamic soil moisture. Thus, we in effect assume that the across-run variability for integrations with climatological soil moisture is similar to that for integrations with dynamic soil moisture. Insofar as we expect the variance in an ensemble of runs with identical, climatological soil moisture to be smaller because specifying the soil moisture removes one of the drivers of variability in climate between runs, our estimates of the significance of differences seen between CLIM and DYNA runs would be conservative.)

Below, we discuss differences between runs primarily as averaged over the land surface (model grid cells with at least $50 \%$ land fraction). Changes averaged over the ocean surface were all much smaller; we mention them when they are significant. We use maps to display the spatial distribution of some of the differences in detail. For seasonal quantities, the tables show averages over the northern midlatitude land surface $\left(15^{\circ}-50^{\circ} \mathrm{N}\right)$ to preserve consistent seasonality.

\section{Results: impact of soil moisture feedback on climate}

\subsection{Mean state}

Because of the nonlinearity of the dependence of evaporation rate on soil moisture, land-surface evaporation was $8 \%$ lower under interactive soil moisture as compared to climatological soil moisture (Table 1), with particularly large decreases in seasonally dry and semiarid tropical and midlatitude areas during summer and fall and in tropical Africa yearround (Fig. 1). Interestingly, evaporation from Siberia in spring increased, because of warmer temperatures and faster snowmelt. Evaporation from the sea surface, which is limited by energy rather than water availability, increased slightly $(0.2 \%)$, because the lower land evaporation decreased relative humidity and warmed the atmosphere, increasing the vapor pressure deficit near the surface. Globally, evaporation decreased $1 \%$.

Since the atmosphere does not store much water, global precipitation decreased by practically the same amount as evaporation (5\% decrease over land; $0.2 \%$ increase over ocean) (Table 1). Precipitation decreases were collocated with and tended to extend some hundred $\mathrm{km}$ downwind (mostly east) of evaporation decreases, reflecting the characteristic length scale for modeled (and observed) water vapor transport and condensation (Trenberth, 1998) (Fig. 2). Precipitation decreases over midlatitude land were limited to the spring and summer, but precipitation decreased in all seasons over the equatorial rain forests of South America, Africa, and Indonesia. A major exception to the decrease in precipitation over land was found in India, where summer rainfall increased substantially (stronger summer monsoon). Inferred runoff (land precipitation minus land evaporation), or water vapor transport onto land, remained almost constant on average. Thus, the decrease in precipitation can be conceptualized as a direct consequence of less evaporation over land (lower precipitation recycling), rather than decreased transport of water vapor from the ocean.

The reduced evaporation increased mean land surface air temperature by $0.2 \mathrm{~K}$ (Table 1 ). This warming was concentrated over the same areas and seasons where evaporation decreased, and regionally reached over $2 \mathrm{~K}$ (Fig. 3). 
Table 1. Impact of dynamic soil moisture on the mean and variance of climate quantities over land.

\begin{tabular}{|c|c|c|c|c|c|c|c|c|c|c|c|c|}
\hline & \multicolumn{3}{|c|}{ Evaporation (mm/day) } & \multicolumn{3}{|c|}{ Precipitation (mm/day) } & \multicolumn{3}{|c|}{ Temperature $\left({ }^{\circ} \mathrm{C}\right)$} & \multicolumn{3}{|c|}{ Cloudiness (\%) } \\
\hline & CLIM & DYNA & & CLIM & DYNA & & CLIM & DYNA & & CLIM & DYNA & \\
\hline Annual mean & 1.67 & 1.53 & $* * *$ & 2.66 & 2.53 & $* * *$ & 9.78 & 10.03 & $* * *$ & 59.1 & 58.9 & $* *$ \\
\hline Interannual SD $\mathrm{SD}^{\mathrm{a}}$ & 0.060 & 0.125 & $* * *$ & 0.166 & 0.182 & * & 0.51 & 0.57 & $* *$ & 0.0505 & 0.0542 & $*$ \\
\hline \multicolumn{13}{|c|}{ Seasonal standard deviation: } \\
\hline winter & 0.174 & 0.313 & $* * *$ & 0.571 & 0.611 & & 1.11 & 1.12 & & 0.165 & 0.168 & \\
\hline spring & 0.155 & 0.309 & $* * *$ & 0.476 & 0.503 & & 0.83 & 0.94 & & 0.146 & 0.144 & \\
\hline summer & 0.124 & 0.308 & $* * *$ & 0.389 & 0.481 & $* *$ & 0.56 & 0.87 & $* * *$ & 0.155 & 0.165 & $*$ \\
\hline fall & 0.114 & 0.289 & $* * *$ & 0.392 & 0.424 & $*$ & 0.70 & 0.83 & $* * *$ & 0.131 & 0.139 & $*$ \\
\hline
\end{tabular}

Significance level of differences between runs: *0.1, **0.05, ***0.01 (two-tailed).

a Standard deviation is dimensionless (normalized by the mean), except for temperature where it is in K.
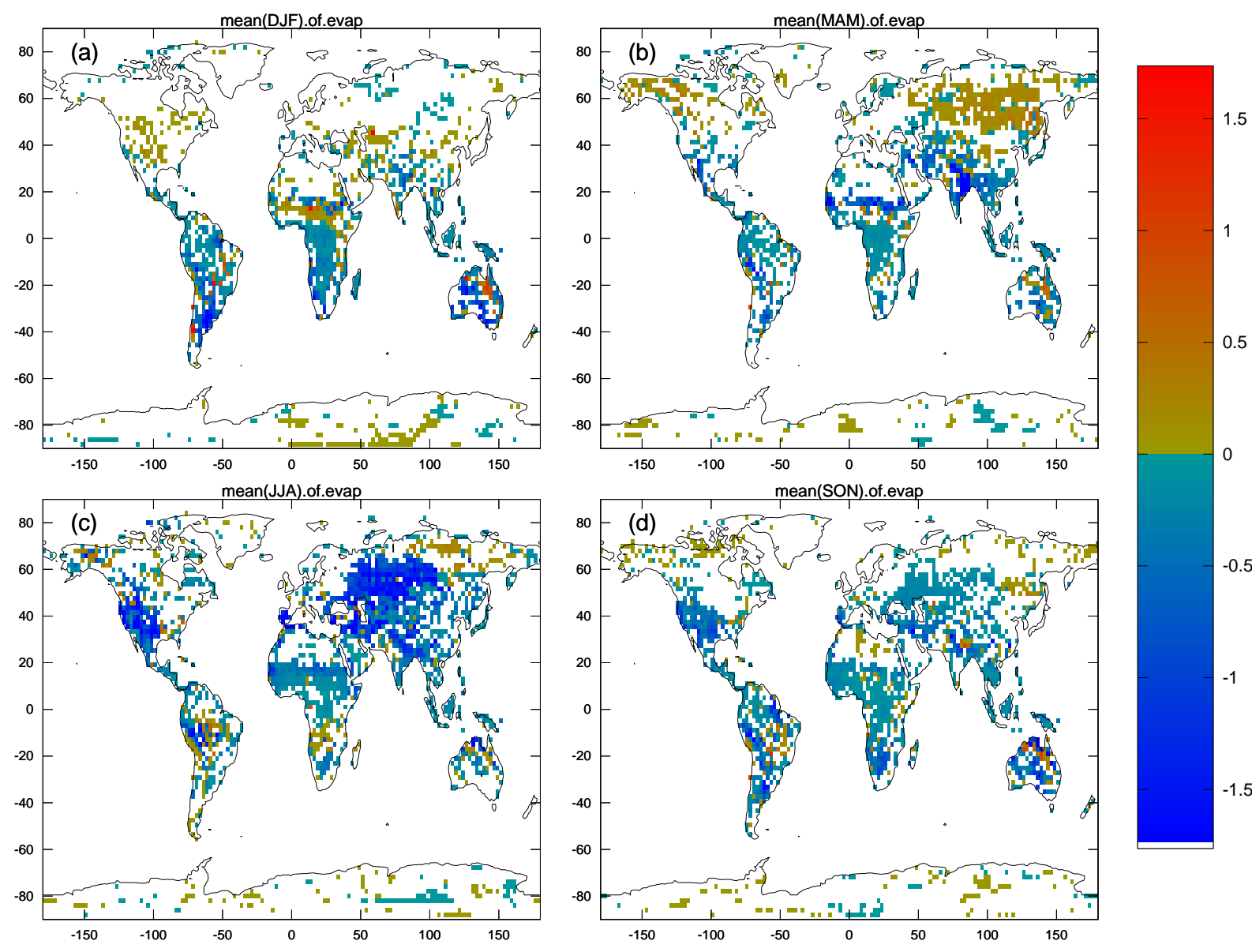

Fig. 1. Change in seasonal evaporation (mm/day) induced by soil moisture feedback (DYNA minus CLIM run). (a) December-JanuaryFebruary (DJF), (b) March-April-May (MAM), (c) June-July-August (JJA), (d) September-October-November (SON). In this and subsequent figures, increases are shown as orange to red, decreases as green to blue; only changes that are over land and are significant at the 0.1 level are shown. 

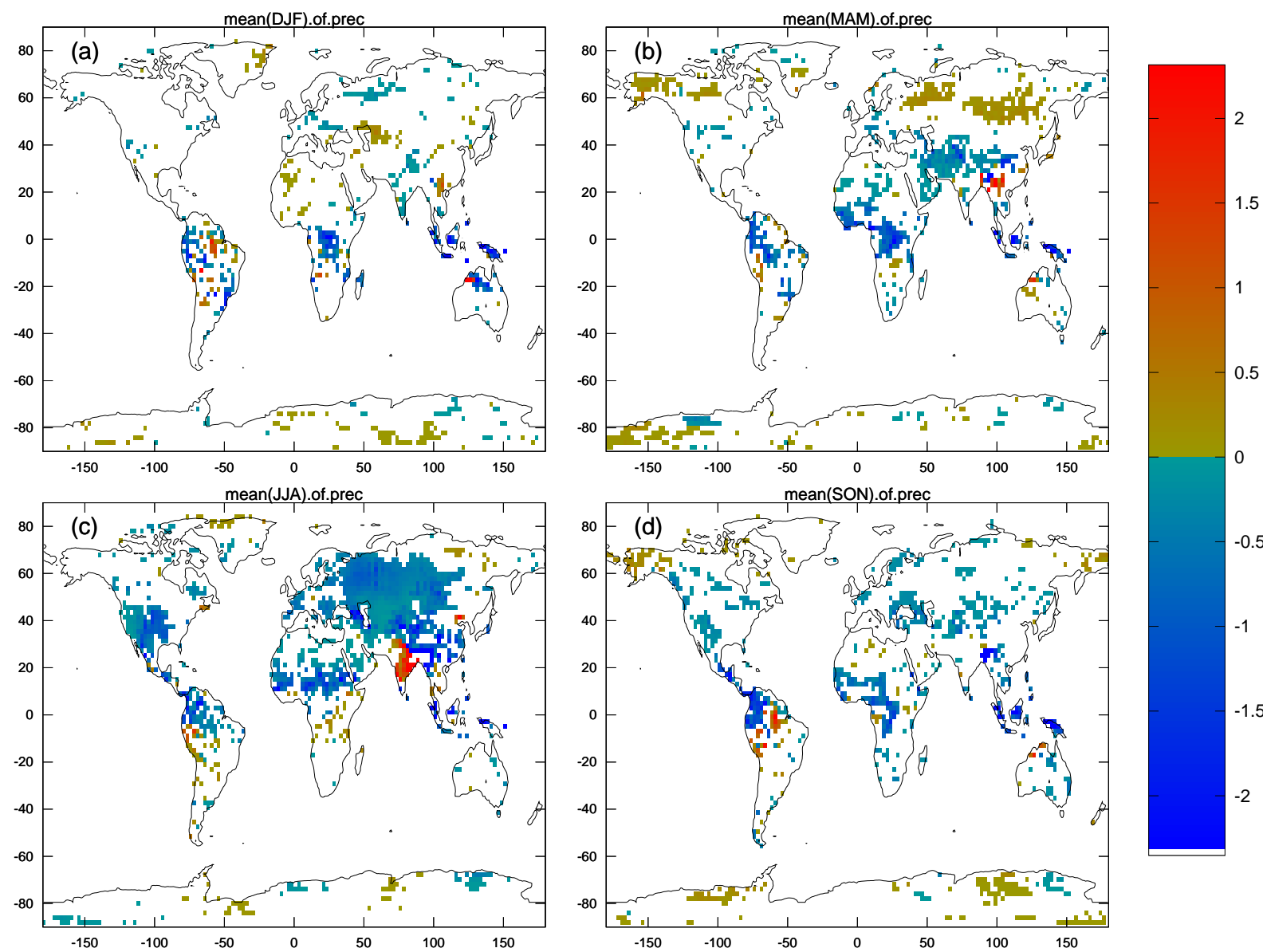

Fig. 2. Change in seasonal precipitation (mm/day) induced by soil moisture feedback (DYNA minus CLIM run). (a) DJF, (b) MAM, (c) JJA, (d) $\mathrm{SON}$

Cloud fraction decreased by $0.2 \%$ over land, concentrated during spring and summer, for which regional decreases were in the $1 \%$ range (Fig. 4). Changes in cloudiness were less likely to be significant on a grid-cell basis than for precipitation and temperature. India was cooler and cloudier in summer (along with more evaporation and precipitation), reflecting a more intense monsoon, though warmer and less cloudy (along with less evaporation and precipitation) in spring. The greater land-sea temperature gradient during spring could plausibly have lead to a stronger summer monsoon.

To illustrate the complexity of seasonally specific mean climate changes seen, Fig. 5 shows the change in monthly mean climate for four representative land grid cells. In the grid cell in the US Great Plains $\left(39^{\circ} \mathrm{N}, 99^{\circ} \mathrm{W}\right)$, evaporation is $20-50 \%$ lower in the DYNA run as compared to the CLIM run from June through October. Precipitation in the DYNA run is already lower in May, presumably because of the advection of moisture anomalies from other grid cells where evaporation is affected in May. Temperatures are 1$3 \mathrm{~K}$ higher for June to October, but cloudiness does not show a consistent change. In the grid cell in eastern Europe near the Urals $\left(47^{\circ} \mathrm{N}, 44^{\circ} \mathrm{E}\right)$, evaporation is strongly suppressed (and cloud fraction reduced by around 5\%) in the DYNA run on August and September but precipitation already decreases, and surface temperatures increase, in July. The maximum warming is $5 \mathrm{~K}$, in August.

In the grid cell in the western Sahel $\left(17^{\circ} \mathrm{N}, 1^{\circ} \mathrm{E}\right)$, precipitation is lower in the DYNA run from the beginning to the peak of the wet season (April to August), as is cloud fraction. Evaporation is lower at the end of the wet season (August to October), and it is somewhat warmer (up to $1 \mathrm{~K}$ ) all year round. In the grid cell in the Amazon $\left(9^{\circ} \mathrm{S}, 61^{\circ} \mathrm{W}\right)$, evaporation declines most strongly in the DYNA as compared with the CLIM run at the height of the dry season (August), but precipitation declines most strongly at the height of the wet season (February and March). Warming is greatest $(0.5-1 \mathrm{~K})$ in August and September, while cloud fraction does not show a consistent change. 

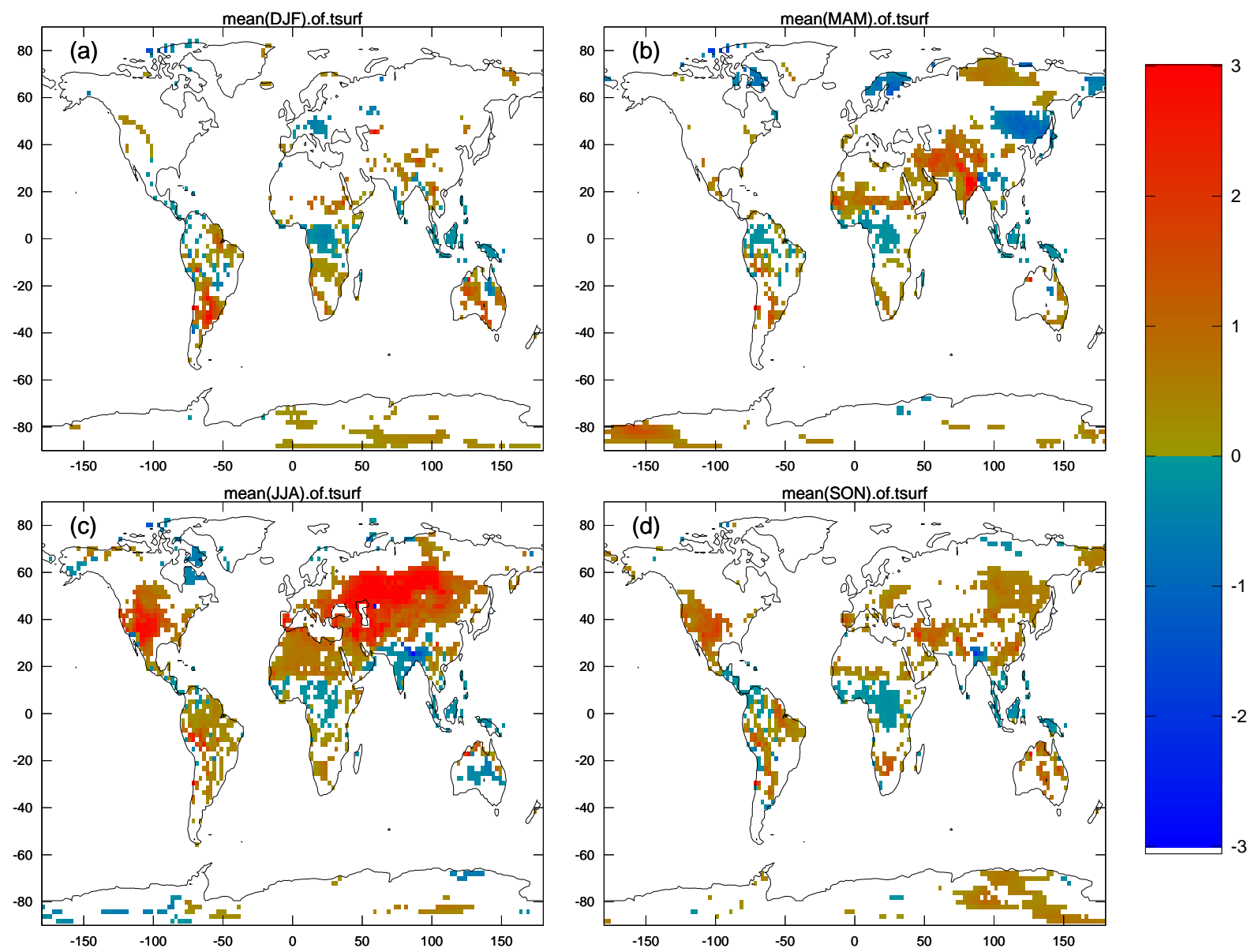

Fig. 3. Change in seasonal surface air temperature (K) induced by soil moisture feedback (DYNA minus CLIM run). (a) DJF, (b) MAM, (c) JJA, (d) SON

\subsection{Interannual variability}

Interactive soil moisture more than doubles the mean interannual standard deviation of land evaporation, illustrating that moisture availability is the major control of land evaporation. Variability in evaporation increases over all seasons, but most in summer and fall (Fig. 6). Temperature variability in the summer extratropics and year-round in the tropics shows a large increase of some $50 \%$ (Fig. 7), suggesting, as also found in previous studies (e.g. Fischer et al., 2007; Conil et al., 2009; Zampieri et al., 2009), that through its control on the fraction of incident energy used for evaporation, soil moisture is an important contributor to summer heat waves.

Particularly large increases in temperature variance are induced in austral summer in inland Australia (Fig. 7a), in austral fall in southern Africa (Fig. 7b), and in boreal summer in North America's Great Plains and in eastern Europe and western Siberia (Fig. 7c). Variability in land precipitation and cloudiness also increase in the summer and fall (Table 1), but this increase is mostly less significant for individual grid cells (not shown).

\subsection{Time correlation}

Time correlation measures the length of, for example, wet and dry spells at a given spot. In both the model and in observed climate, correlation between consecutive years in precipitation and cloudiness is very weak over most of the earth's surface, while correlation in temperature and evaporation is somewhat stronger, driven by slowly varying patterns of SST anomalies (Table 2). The autocorrelation of annual evaporation decreases as a result of soil moisture feedback, because evaporation now depends, via soil moisture, on precipitation (which varies more rapidly) more than on temperature (which varies more slowly). By contrast, soil moisture feedback increases the shorter-term correlation between spring and summer and between summer and fall for temperature and evaporation, as soil moisture provides a seasonal-scale "memory" that propagates wet-cool or dryhot patterns during the warm half of the year (Table 2). Soil moisture feedback decreases the correlation between fall and winter precipitation, perhaps because fall precipitation now depends more on soil moisture whereas winter precipitation 
Table 2. Impact of dynamic soil moisture on the space and time correlation of climate quantities over land.

\begin{tabular}{|c|c|c|c|c|c|c|c|c|c|c|c|}
\hline & \multicolumn{3}{|c|}{ Evaporation } & \multicolumn{3}{|c|}{ Precipitation } & \multicolumn{3}{|c|}{ Temperature } & \multicolumn{2}{|c|}{ Cloudiness } \\
\hline & CLIM & \multicolumn{2}{|c|}{ DYNA } & CLIM & \multicolumn{2}{|l|}{ DYNA } & CLIM & \multicolumn{2}{|l|}{ DYNA } & CLIM & DYNA \\
\hline \multicolumn{12}{|c|}{ Interannual autocorrelation time scale (y) } \\
\hline & 0.47 & 0.41 & $*$ & 0.27 & 0.28 & & 0.44 & 0.42 & & 0.30 & 0.30 \\
\hline \multicolumn{12}{|c|}{ 3-month autocorrelation } \\
\hline winter-spring & 0.02 & 0.04 & & 0.00 & 0.02 & & 0.02 & 0.01 & & 0.01 & 0.03 \\
\hline spring-summer & 0.07 & 0.16 & $*$ & 0.03 & 0.10 & & 0.07 & 0.18 & $* * *$ & 0.04 & 0.10 \\
\hline summer-fall & 0.08 & 0.19 & $* *$ & 0.03 & 0.10 & & 0.13 & 0.16 & $*$ & 0.02 & 0.13 \\
\hline fall-winter & 0.01 & 0.02 & & 0.04 & 0.00 & $*$ & 0.00 & -0.01 & & 0.03 & 0.02 \\
\hline \multicolumn{12}{|c|}{ annual correlation length (km) } \\
\hline & 562 & 514 & & 742 & 848 & & 5994 & 4840 & $* * *$ & 860 & 884 \\
\hline \multicolumn{12}{|c|}{ seasonal correlation length (km) } \\
\hline winter & 578 & 683 & & 858 & 901 & & 2192 & 2163 & & 1291 & 1205 \\
\hline spring & 549 & 518 & & 752 & 836 & & 1980 & 1644 & & 970 & 1133 \\
\hline summer & 577 & 636 & & 893 & 1065 & $* *$ & 1895 & 1683 & & 845 & 877 \\
\hline fall & 516 & 583 & & 713 & 824 & & 1889 & 1428 & $* *$ & 905 & 881 \\
\hline
\end{tabular}

Significance level of differences between runs: $* 0.1, * * 0.05, * * * 0.01$ (two-tailed).
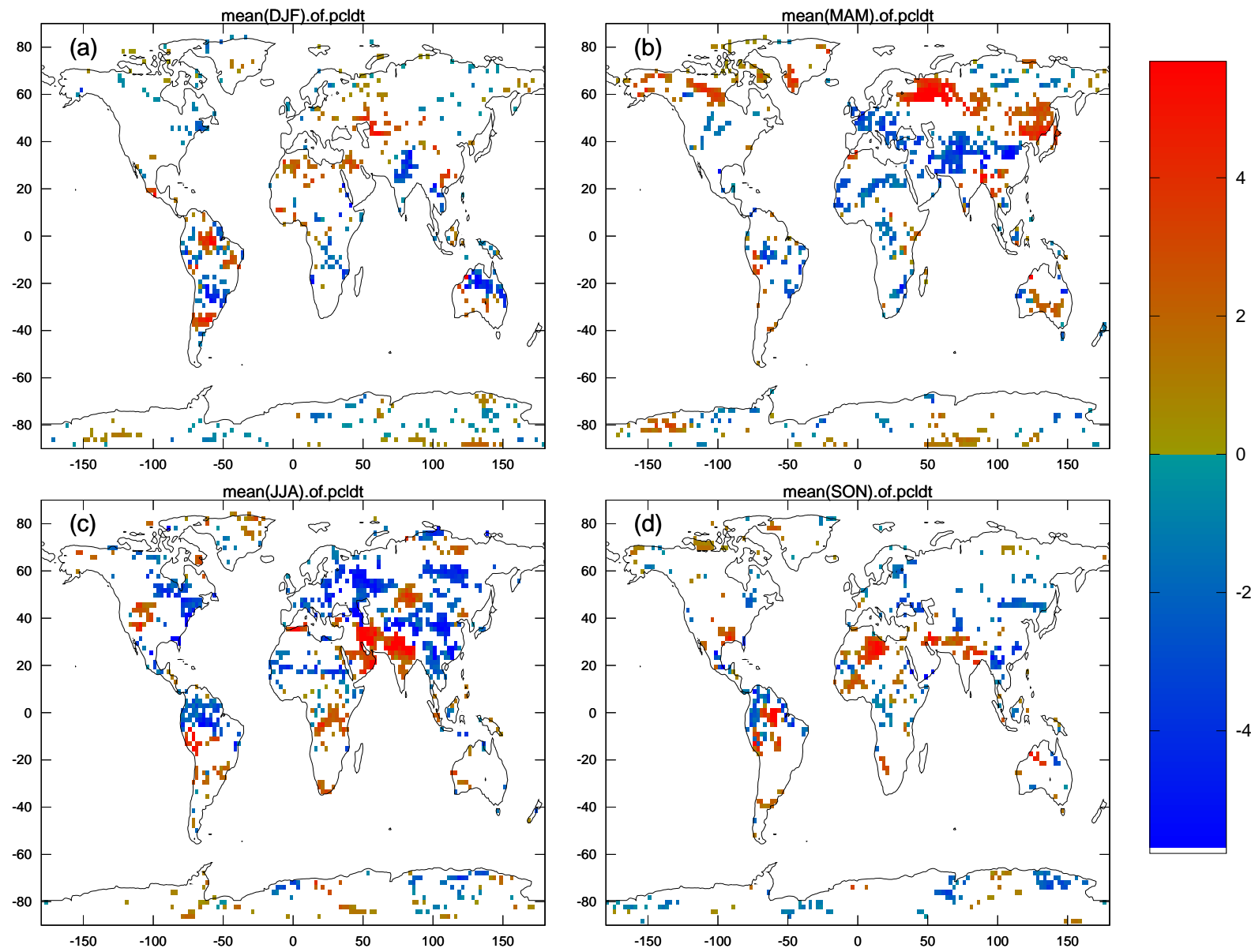

Fig. 4. Change in seasonal cloud cover (\%) induced by soil moisture feedback (DYNA minus CLIM run). (a) DJF, (b) MAM, (c) JJA, (d) $\mathrm{SON}$ 
$\operatorname{evap} 39^{\circ} \mathrm{N},-99^{\circ} \mathrm{E}$
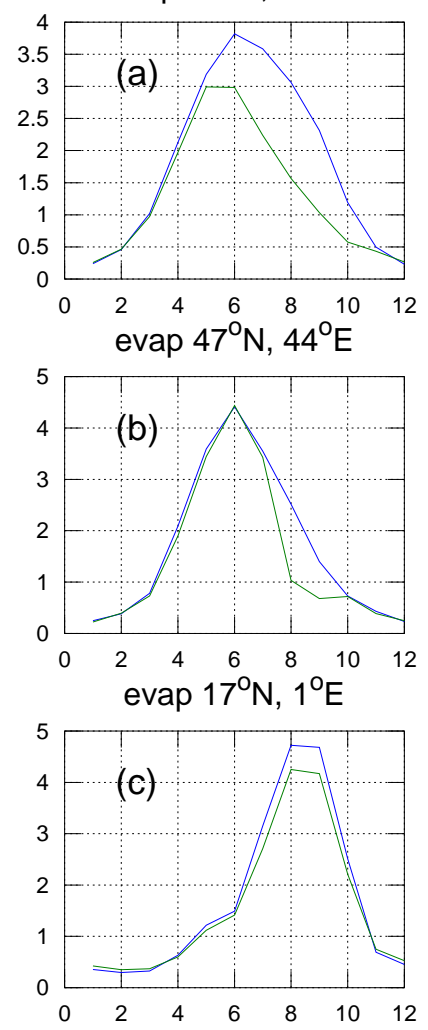

evap $-9^{\circ} \mathrm{N},-61^{\circ} \mathrm{E}$

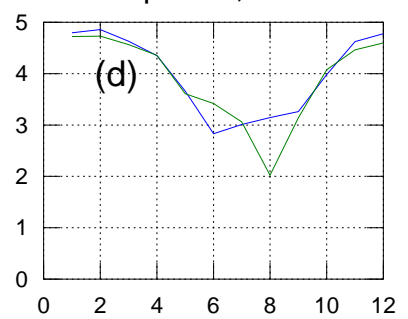

prec $39^{\circ} \mathrm{N},-99^{\circ} \mathrm{E}$
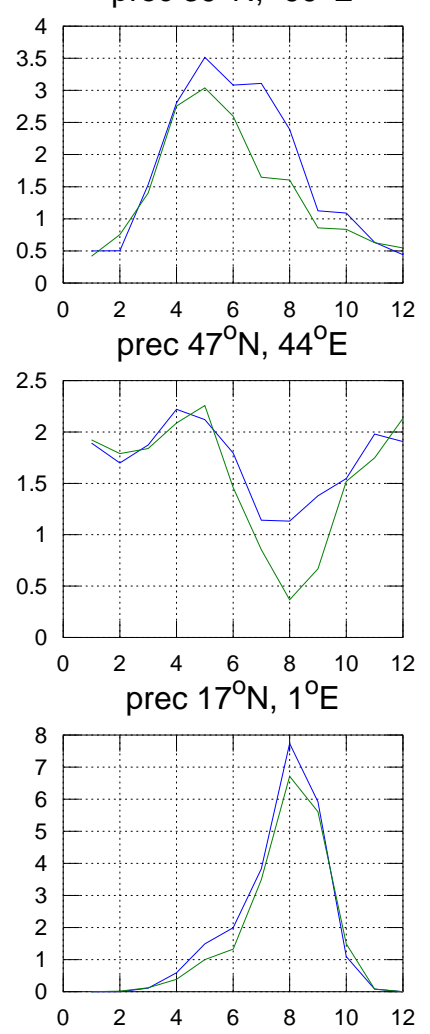

prec $-9^{\circ} \mathrm{N},-61^{\circ} \mathrm{E}$

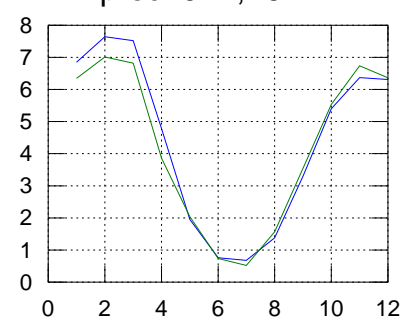

tsurf $39^{\circ} \mathrm{N},-99^{\circ} \mathrm{E}$
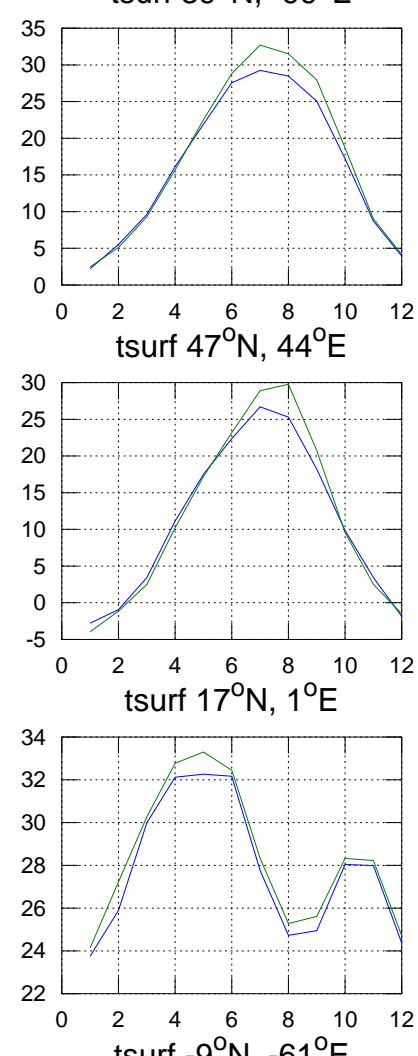

tsurf $-9^{\circ} \mathrm{N},-61^{\circ} \mathrm{E}$

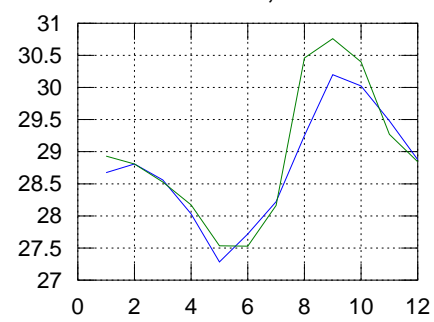

pcldt $39^{\circ} \mathrm{N},-99^{\circ} \mathrm{E}$
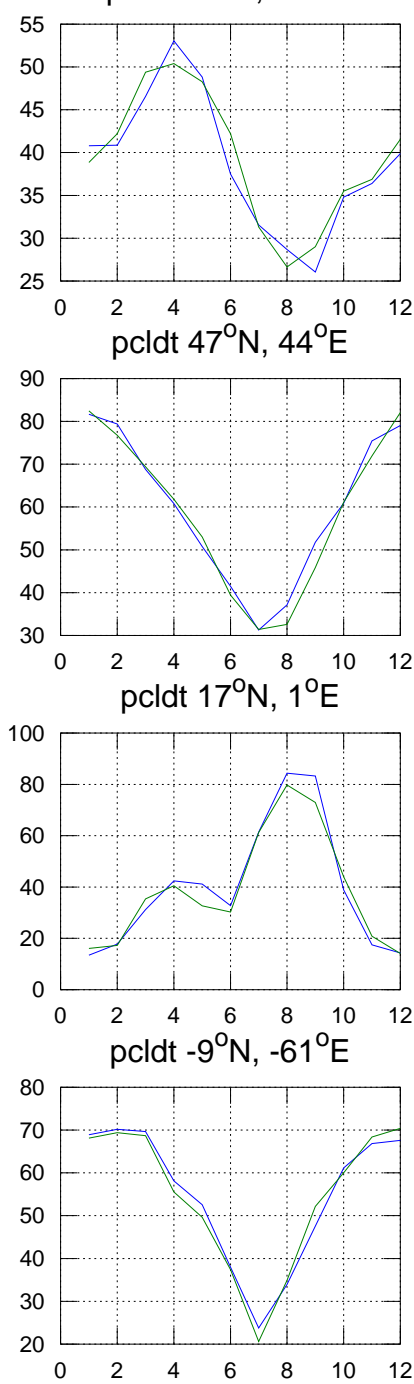

Fig. 5. Monthly mean climate for four representative grid points: (a) US Great Plains $\left(39^{\circ} \mathrm{N} 99^{\circ} \mathrm{W}\right)$, (b) eastern Europe $\left(47^{\circ} \mathrm{N} 44^{\circ} \mathrm{E}\right)$, (c) the Sahel $\left(17^{\circ} \mathrm{N} 1^{\circ} \mathrm{E}\right)$, (d) the Amazon basin $\left(9^{\circ} \mathrm{S} 61^{\circ} \mathrm{W}\right)$. From left to right, the columns show evaporation (mm/day), precipitation $(\mathrm{mm} /$ day $)$, temperature $\left({ }^{\circ} \mathrm{C}\right)$, and cloud fraction $(\%)$. Blue lines are for CLIM run, green lines DYNA run.

still depends only on basically unrelated variations in largescale circulation (Table 2). At the grid-cell level changes in the inter-seasonal correlation of climate variables were mostly not significant, but noteworthy regional impacts include an increase in the correlation of fall with winter evaporation in southern Africa (wet-season moisture anomalies persisting into the dry season) and an increase in the correlation of spring with summer temperature in much of the central and western United States (not shown).

\subsection{Space correlation}

The correlation length provides an indication of the spatial extent of annual or seasonal scale climate anomalies (for example, the typical spatial extent of a drought). The mean correlation length for annual temperature $(\sim 5000 \mathrm{~km})$ is much longer than that for annual precipitation or cloudiness $(\sim 800 \mathrm{~km})$ (Table 2$)$. This is in part because temperature variability is largely determined by interannual seasurface temperature patterns with large spatial scale, while these patterns are less influential for precipitation and cloudiness variability. (The length scale for temperature is particularly long in the tropics, because dynamical adjustment of the atmosphere tends to rapidly dissipate temperature perturbations; e.g. Sobel et al., 2001.) The correlation length of annual evaporation is smaller yet $(\sim 500 \mathrm{~km})$, perhaps because small-scale variation in soil texture, topography, and land cover modulates the response of evaporation to variations in precipitation. 

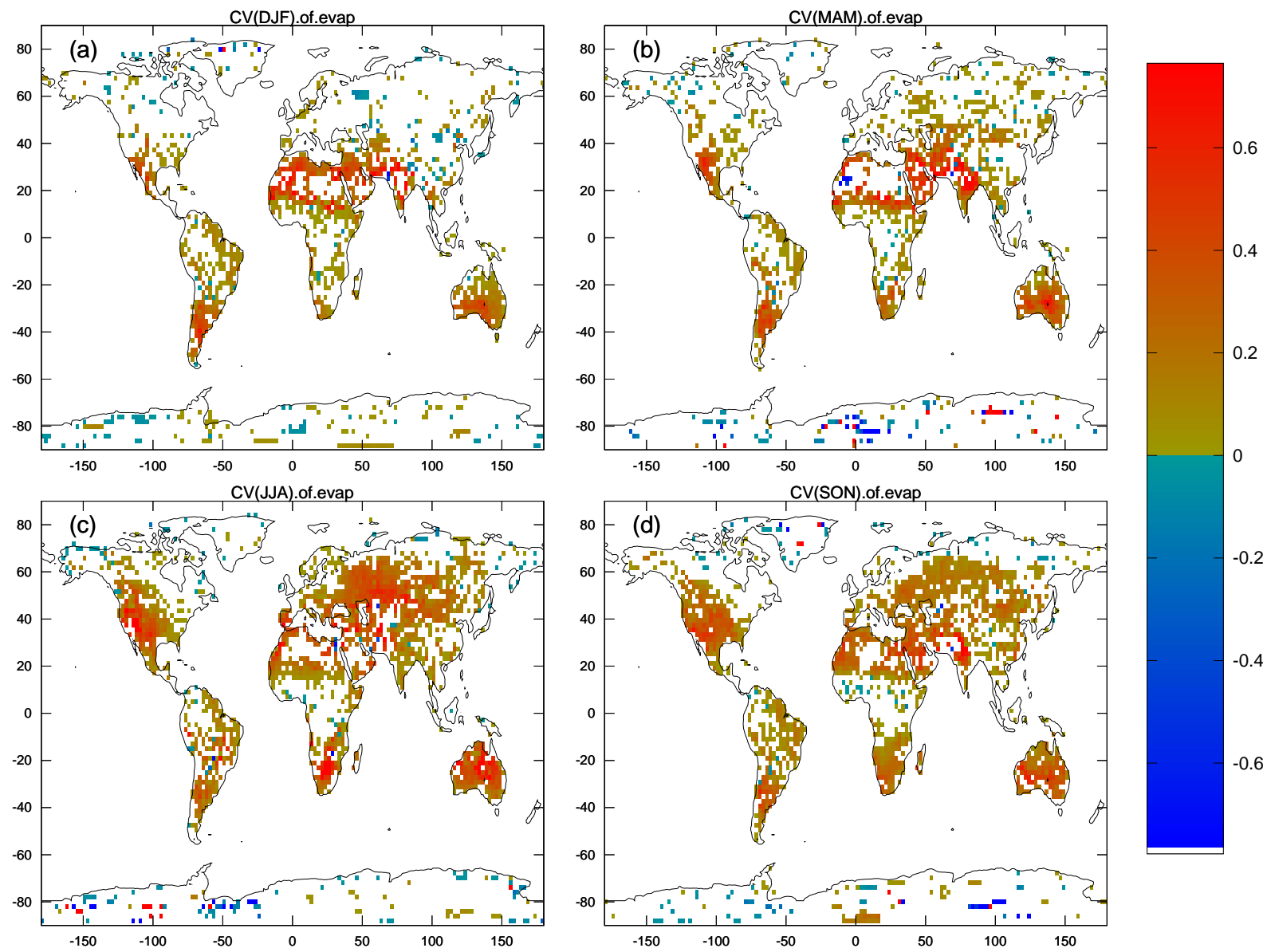

Fig. 6. Change in interannual coefficient of variation of seasonal evaporation (unitless) induced by soil moisture feedback (DYNA minus CLIM run). (a) DJF, (b) MAM, (c) JJA, (d) SON.

Soil moisture feedback tends to decrease the correlation length of evaporation because it makes evaporation strongly dependent on recent precipitation (short correlation length) as well as temperature (long correlation length); the decrease is regionally significant over North America, east Asia, and the Amazon basin (Fig. 8), although the global average does not show a significant difference (Table 2). Soil moisture feedback might be expected to increase the correlation length scale of precipitation on seasonal time scales because it makes precipitation dependent on earlier upwind precipitation. Indeed, the correlation length of seasonal precipitation does increase in summer (Table 2).

Soil moisture feedback decreases the correlation length of temperature over land dramatically (by 19\% (Table 2); by $4 \%$ over ocean), because temperature variability now depends on precipitation and soil moisture (with much smaller scales of variability) via the greatly enhanced variability in land evaporation. In fact, the correlation length of temperature over land is modeled to be more than that over ocean without soil moisture feedback, but less than that over ocean with soil moisture feedback (not shown). The correlation length of seasonal temperature decreases in fall (Table 2), reflecting the coupling of temperature and precipitation variability induced by soil moisture feedback, primarily over North America (Fig. 9). In the tropics, the temparture correlation length scale tends to decrease year-round (Fig. 9). The role of soil moisture feedback in coupling temperature and precipitation can also be seen from the correlation between seasonal temperature and precipitation, which over land becomes substantially more negative as a result of soil moisture feedback (Fig. 10).

\section{Discussion}

\subsection{Global and regional impacts of soil moisture feedback}

We have used several metrics to summarize how soil moisture feedback affects climate on a planetary scale, reaching conclusions broadly consistent with those of previous case studies and forecasting experiments. Soil moisture feedback 

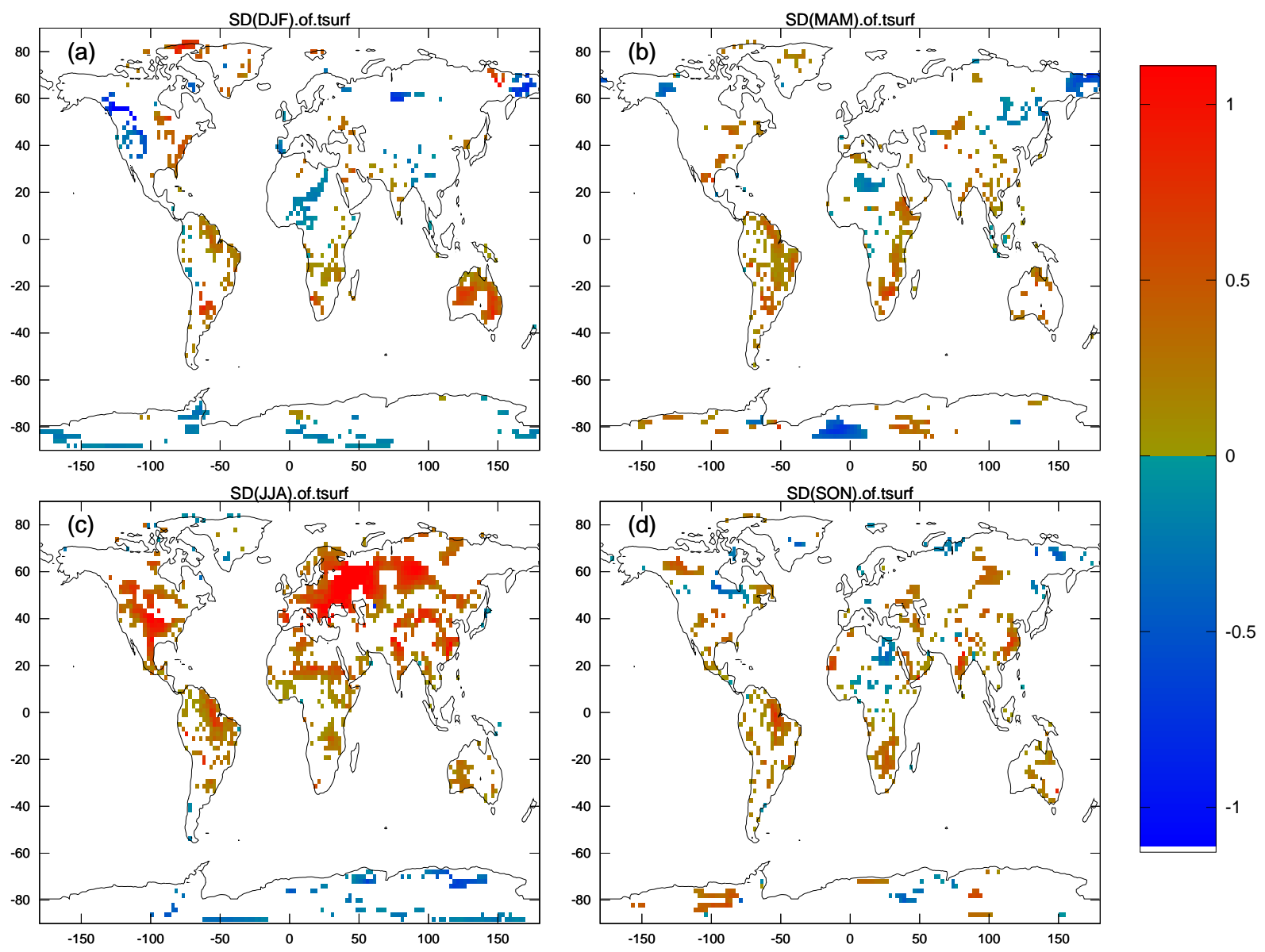

Fig. 7. Change in interannual standard deviation of seasonal temperature (K) induced by soil moisture feedback (DYNA minus CLIM run). (a) DJF, (b) MAM, (c) JJA, (d) SON.

makes annual and seasonal (warm-season) land evaporation, precipitation, temperature, and cloudiness substantially more variable. It introduces persistence of cool-wet or hot-dry conditions from spring through fall. This would be expected to have important impacts on land ecosystems, particularly in water-limited areas. Dynamic vegetation responses (not modeled here) would be expected to amplify climate perturbations further compared to a hypothetical condition of no vegetation and low soil moisture capacity, so that there could even exist two fundamentally different possible equilibrium climate states (vegetated-wet or barren-dry; Baudena et al., 2008).

Impacts over the ocean from soil moisture feedback are expected to be smaller and less direct than over land, but are underestimated here because the ocean state was prescribed rather than allowed to evolve in response to atmospheric forcing. A long integration time with coupled atmosphere and ocean would be necessary to properly quantify the two-way interaction of soil moisture and sea surface temperature in affecting climate variability. Abbot and Emanuel (2007) demonstrated that such feedbacks can be important in an idealized few-box model of atmosphere-sea-land interaction.

The change in the mean evaporation rate and climate state between the climatological and interactive soil moisture runs is largely the opposite of that seen in the runs reported by Reale and Dirmeyer (2002). In their simulations, dynamic, as compared with climatological, soil moisture resulted in higher land evaporation and precipitation (and lower ocean evaporation and precipitation), whereas in our simulations land evaporation and precipitation substantially decreased (while ocean evaporation and precipitation slightly increased). This can be qualitatively understood in terms of the different strategies we used to set climatological soil moisture. Whereas here we set soil moisture for each month to its climatology, Reale and Dirmeyer (2002) instead prescribed a climatology of the "evaporation factor" (actual evapotranspiration, summed over a month, as a fraction of potential evapotranspiration). The nonlinearity of evaporation as a function of state variables such as soil moisture and temperature means that these two approaches bias land evaporation rate in opposite senses. At moderate soil moisture 

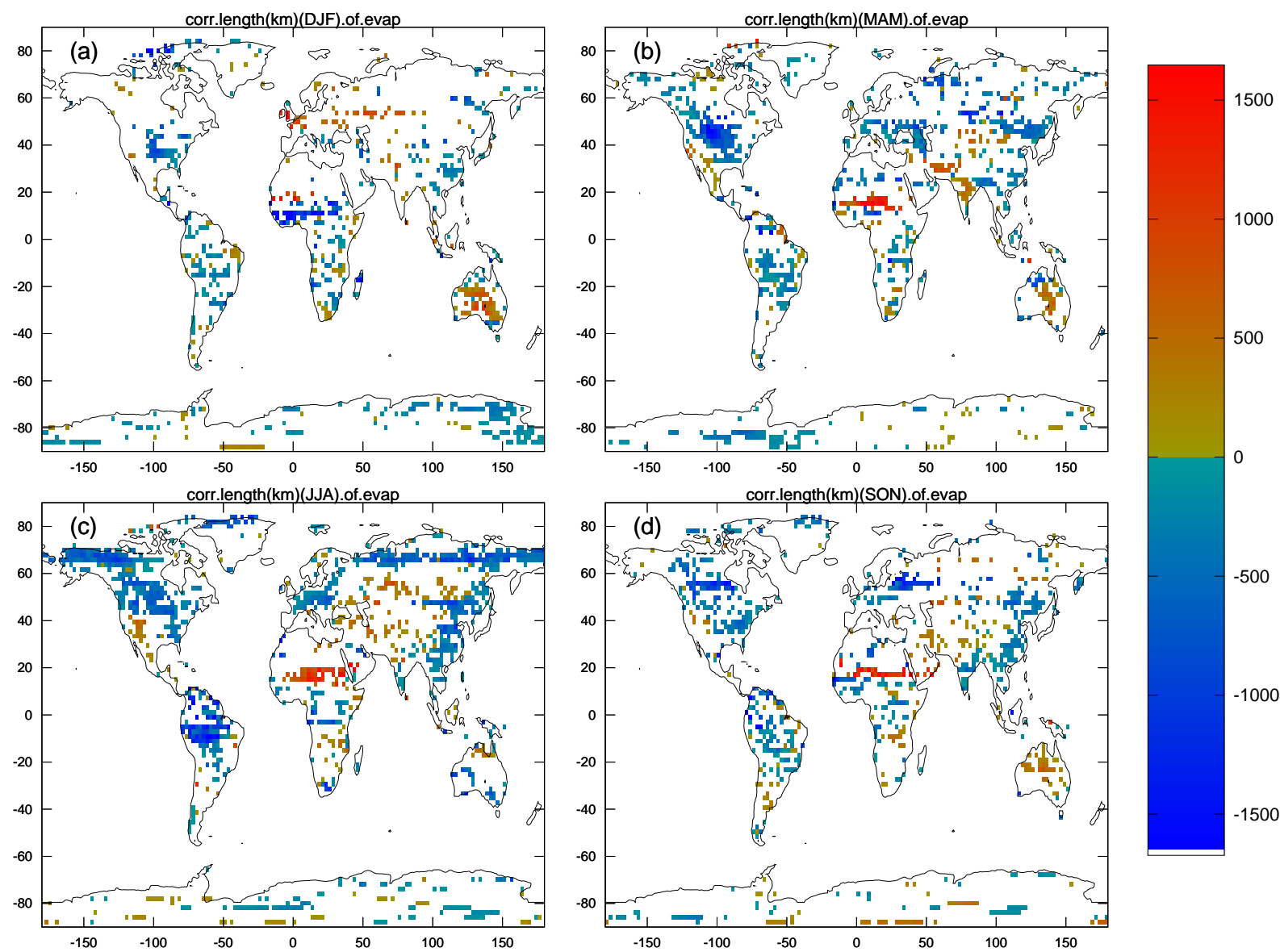

Fig. 8. Change in east-west correlation length scale for seasonal evaporation (km) induced by soil moisture feedback (DYNA minus CLIM run). (a) DJF, (b) MAM, (c) JJA, (d) SON.

content, the increase of evaporation with soil moisture has negative curvature (is concave), so prescribing average soil moisture results in higher than average evaporation. On the other hand, the evaporation factor is higher than climatology at night and under cool conditions, and lower than climatology under hot, dry conditions. Prescribing it to be constant leads to high evaporation in hot, dry conditions, which reduces otherwise high vapor pressure deficits and thus cuts potential evapotranspiration. Since the actual evapotranspiration is a prescribed fraction of potential evapotranspiration, the former is also reduced. Consistent with this explanation, increases in land precipitation under dynamic as compared to fixed soil moisture were reported by Koster and Suarez (1995) and Koster et al. (2000), who also prescribed the evaporation factor instead of the soil moisture content.

The observed changes in the mean climate are therefore dependent on the specific climatology adopted for soil moisture and/or evaporation and do not result from the difference between dynamic and climatological soil moisture as such. This introduces some ambiguity into interpreting model experiments such as the one reported here. However, unlike the changes in the mean climate state, the changes in climate variability (for example, higher interannual variance of precipitation with dynamic soil moisture) reported by Reale and Dirmeyer (2002) were similar to those we found, which suggests that these changes can be more confidently interpreted as an effect of dynamic soil moisture as such. If so, analysis of the space and time scales of observed climate variability could potentially help quantify the actual strength of soil moisture feedback and determine which models represent it most accurately.

The substantial change observed in the mean state, especially in summer temperature and precipitation, is interesting in that our formulation of interannually fixed soil moisture can be thought of as similar to high soil water capacity (which would also lead to reduced synoptic and interannual variability in volumetric soil moisture). The impact on land climate of changing soil water capacity, whether over evolutionary time as plants and soils shift or in historic time as a result of deforestation and tillage, would be an intriguing target for future research. 

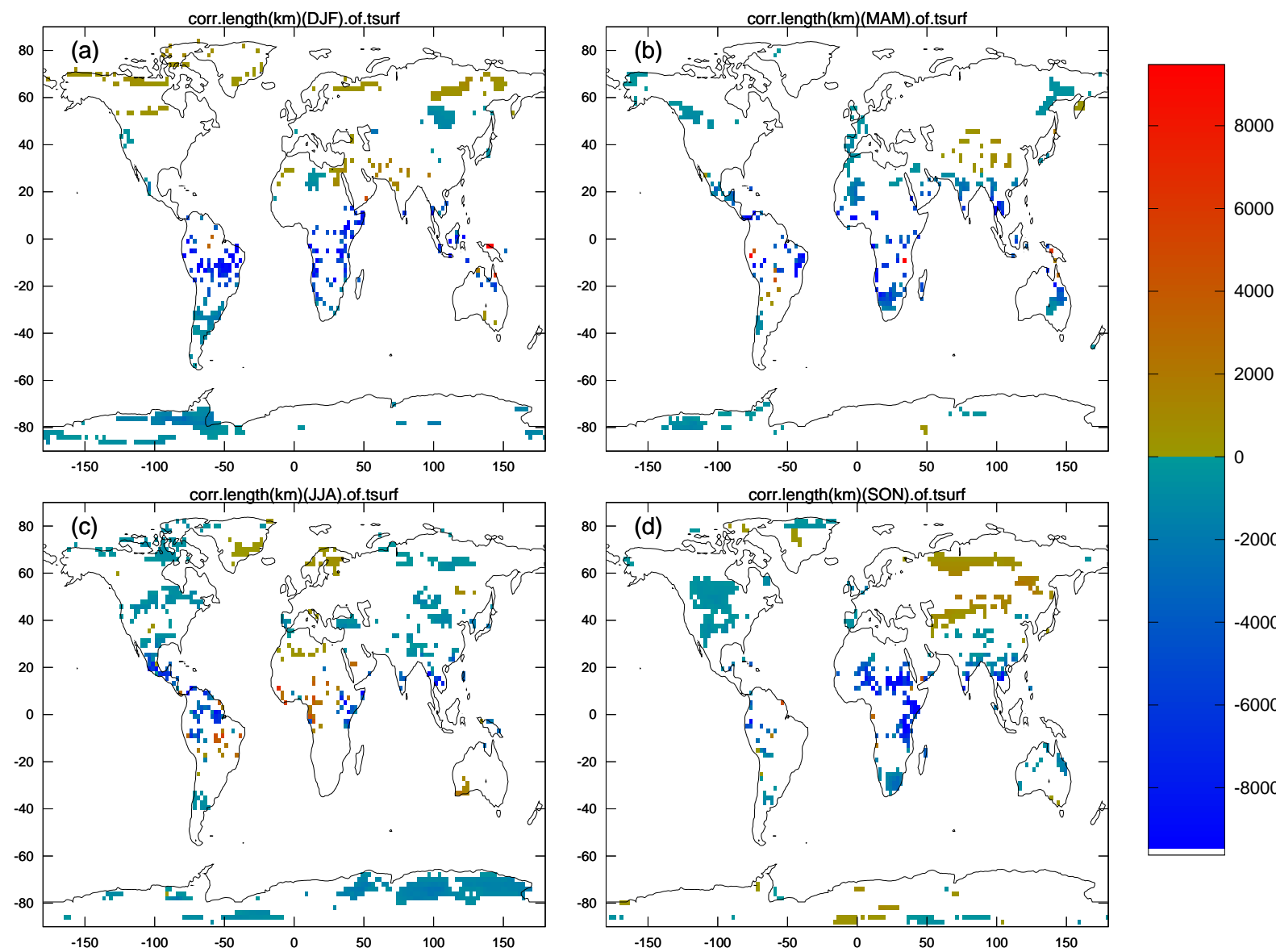

Fig. 9. Change in east-west correlation length scale for seasonal temperature (km) induced by soil moisture feedback. (a) DJF, (b) MAM, (c) JJA, (d) SON.

In our model integrations, soil moisture, and hence evaporation, perturbations were reflected in local temperature change (from surface evaporative cooling) and downwind precipitation change. The precise length/time scale over which precipitation responds to additional evaporation depends on subgrid condensation processes and therefore varies substantially among current global models (Koster et al., 2004). While this limitation may not affect the globalscale results very much, regional models where convection is either more explicitly resolved or whose parameterization has been validated in detail would be recommended for studying the impacts of regional changes in soil moisture, for example from irrigation or no-till agriculture, at better resolution.

\subsection{Soil moisture feedback and interannual persistence}

We were not able to show a significant impact of soil moisture feedback on the year-to-year persistence of precipitation or other climate variables. The year-to-year autocorrelations of climate variables tend to be low, and a longer period than
30 years may be necessary to detect a significant difference in interannual persistence. Schubert et al. (2004) found that 50year periods in a 200-year run do not show consistent yearto-year persistence of precipitation and soil moisture in the Great Plains, although their full run does.

An additional factor affecting soil moisture feedback in our and most previous global modeling efforts is that the model soil depth is no more than $3.5 \mathrm{~m}$, limiting the effective water capacity of the soil and hence the time over which it integrates precipitation history. In fact, soils can be many meters deep, and the root systems of trees and grasses are known to access water from deep in the soil profile (Stone and Kalisz, 1991; Richter and Markowitz, 1995; Kleidon and Heimann, 1998). This has been studied most thoroughly in seasonally dry parts of the Amazon rainforest, where trees are found to access water down to at least $10 \mathrm{~m}$ depth, enabling high rates of evapotranspiration and photosynthesis to continue through dry seasons and drought years (Nepstad et al., 1994; da Rocha et al., 2004; Huete et al., 2006). Water stored within trees can also be important in seasonally dry tropical forests (Borchert, 1994), as can hydraulic 

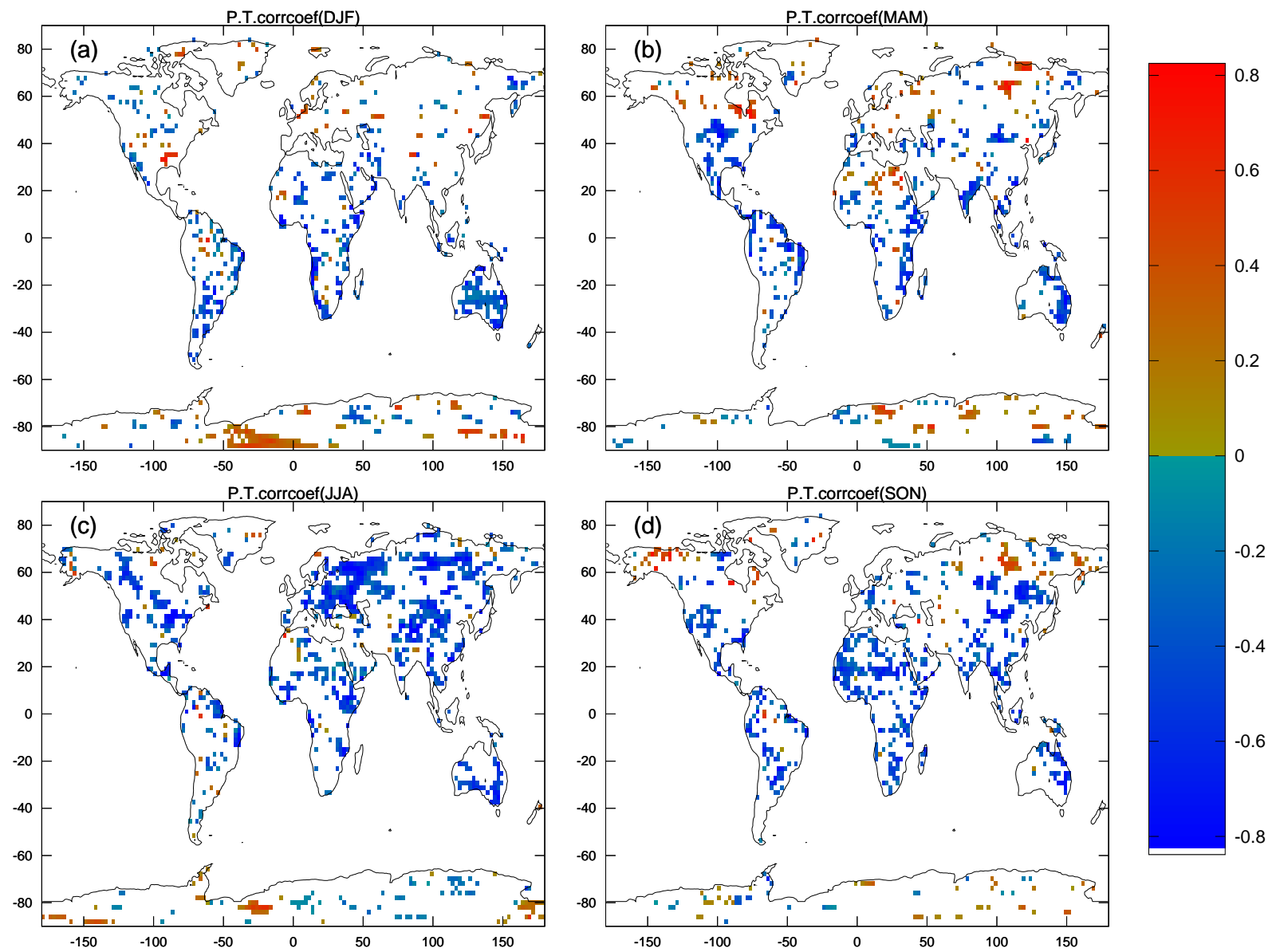

Fig. 10. Change in correlation coefficient between seasonal temperature and precipitation (dimensionless) induced by soil moisture feedback (DYNA minus CLIM run). Negative values mean that the correlation coefficient $(r)$ became more negative, not that the strength of the correlation $\left(r^{2}\right)$ was reduced. (a) DJF, (b) MAM, (c) JJA, (d) SON.

redistribution (active vertical transport of water within the soil profile by plant roots) (Oliveira et al., 2005). Model simulations with deeper soil, an explicit water table (Maxwell et al., 2007; Niu et al., 2007), and representation of hydraulic redistribution (Lee et al., 2005) and plant water storage should be able to better resolve the role of soil moisture feedback in long-term variability.

\section{Conclusions}

We have shown how soil moisture feedback affects planetary climate in a general circulation model simulation. Soil moisture feedback makes a large contribution to variability in temperature, precipitation, and cloudiness under warm conditions. Analysis of space and time scales of climate variables further elucidates how soil moisture feedback induces cool-wet and hot-dry seasonal patterns. Longer runs and more realistic treatment of deep soil and groundwater are required to evaluate the contribution of soil moisture feedback to interannual variability, such as multiyear droughts. The soil moisture feedback impacts found here provide new targets for comparisons across models and with observations.

Acknowledgement. This study was supported by the National Oceanic and Atmospheric Administration (NOAA) under Grant Number NA06OAR4810162. The statements contained in this article are not the opinions of the funding agency or the US government, but reflect the views of the authors.

Edited by: B. Schaefli 


\section{References}

Abbot, D. S. and Emanuel, K. A.: A tropical and subtropical landsea-atmosphere drought oscillation mechanism, J. Atmos. Sci., 64, 4458-4468, 2007.

Abramopoulos, F., Rosenzweig, C., and Choudhury, B.: Improved ground hydrology calculations for global climate models (GCMs): soil water movement and evapotranspiration, J. Climate, 1, 921-941, doi:10.1175/1520-0442(1988)001<0921: IGHCFG) 2.0.CO;2, 1988.

Aleinov, I. and Schmidt, G.: Water isotopes in the GISS ModelE land surface scheme, Global Planet. Change, 51, 108-120, doi: 10.1016/j.gloplacha.2005.12.010, 2006.

Baudena, M., D’Andrea, F., and Provenzale, A.: A model for soilvegetation-atmosphere interactions in water-limited ecosystems, Water Resour. Res., 44, W12429, doi:10.1029/2008WR007172, 2008.

Borchert, R.: Soil and stem water storage determine phenology and distribution of tropical dry forest trees, Ecology, 75, 1437-1449, 1994.

Charney, J., Stone, P. H., and Quirk, W. J.: Drought in the Sahara: a biogeophysical feedback mechanism, Science, 187, 434-435, doi:10.1126/science.187.4175.434, 1975.

Conil, S., Douville, H., and Tyteca, S.: The relative influence of soil moisture and SST in climate predictability explored within ensembles of AMIP type experiments, Clim. Dynam., 28, 125145, doi:10.1007/s00382-006-0172-2, 2007.

Conil, S., Douville, H., and Tyteca, S.: Contribution of realistic soil moisture initial conditions to boreal summer climate predictability, Clim. Dynam., 32, 75-93, doi:10.1007/s00382-008-0375-9, 2009.

Cook, B. I., Miller, R. L., and Seager, R.: Dust and sea surface temperature forcing of the 1930s "Dust Bowl" drought, Geophys. Res. Lett., 35, L08710, doi:10.1029/2008GL033486, 2008.

Cook, B. I., Miller, R. L., and Seager, R.: Amplification of the North American "Dust Bowl" drought through human-induced land degradation, P. Natl. Acad. Sci. USA, 106, 4997-5001, doi: 10.1073/pnas.0810200106, 2009.

da Rocha, H. R., Goulden, M. L., Miller, S. D., Menton, M. C., Pinto, L. D. V. O., de Freitas, H. C., and e Silva Figueira, A. M.: Seasonality of water and heat fluxes over a tropical forest in eastern Amazonia, Ecol. Appl., 14, 22-32, doi:10.1890/02-6001, 2004.

Delworth, T. and Manabe, S.: The influence of soil wetness on nearsurface atmospheric variability, J. Climate, 2, 1447-1462, doi: 10.1175/1520-0442(1989)002〈1447:TIOSWO $\rangle 2.0 . C O ; 2,1989$.

Dirmeyer, P. A., Koster, R. D., and Guo, Z.: Do global models properly represent the feedback between land and atmosphere?, J. Hydrometeorol., 7, 1177-1198, 2006.

Findell, K. L. and Eltahir, E. A. B.: An analysis of the soil moisturerainfall feedback, based on direct observations from Illinois, Water Resour. Res., 33, 725-735, 1997.

Fischer, E. M., Seneviratne, S. I., Vidale, P. L., Luthi, D., and Schar, C.: Soil moisture - atmosphere interactions during the $2003 \mathrm{Eu}-$ ropean summer heat wave, J. Climate, 20, 5081-5099, 2007.

Friend, A. D. and Kiang, N. Y.: Land surface model development for the GISS GCM: Effects of improved canopy physiology on simulated climate, J. Climate, 18, 2883-2902, doi: 10.1175/JCLI3425.1, 2005.
Hansen, J., Sato, M., Ruedy, R., Kharecha, P., Lacis, A., Miller, R., Nazarenko, L., Lo, K., Schmidt, G. A., Russell, G., Aleinov, I., Bauer, S., Baum, E., Cairns, B., Canuto, V., Chandler, M., Cheng, Y., Cohen, A., Genio, A. D., Faluvegi, G., Fleming, E., Friend, A., Hall, T., Jackman, C., Jonas, J., Kelley, M., Kiang, N. Y., Koch, D., Labow, G., Lerner, J., Menon, S., Novakov, T., Oina, V., Perlwitz, J., Perlwitz, J., Rind, D., Romanou, A., Schmunk, R., Shindell, D., Stone, P., Sun, S., Streets, D., Tausnev, N., Thresher, D., Unger, N., Yao, M., and Zhang, S.: Climate simulations for 1880-2003 with GISS modelE, Clim. Dynam., 29, 661-696, doi:10.1007/s00382-007-0255-8, 2007.

Hohenegger, C., Brockhaus, P., Bretherton, C. S., and Schär, C.: The soil moisture-precipitation feedback in simulations with explicit and parameterized convection, J. Climate, 22, 5003-5020, doi:10.1175/2009JCLI2604.1, 2009.

Hong, S.-Y. and Kalnay, E.: Role of sea surface temperature and soil-moisture feedback in the 1998 Oklahoma-Texas drought, Nature, 408, 842-844, doi:10.1038/35048548, 2000.

Huete, A. R., Didan, K., Shimabukuro, Y. E., Ratana, P., Saleska, S. R., Hutyra, L. R., Yang, W., Nemani, R. R., and Myneni, R.: Amazon rainforests green-up with sunlight in dry season, Geophys. Res. Lett., 33, L06405, doi:10.1029/2005GL025583, 2006.

Jeong, J.-H., Ho, C.-H., Chen, D., and Park, T.-W.: Land surface initialization using an offline CLM3 simulation with the GSWP2 forcing dataset and its impact on CAM3 simulations of the boreal summer climate, J. Hydrometeorol., 9, 1231-1248, doi: 10.1175/2008JHM941.1, 2008.

Kleidon, A. and Heimann, M.: Optimised rooting depth and its impacts on the simulated climate of an atmospheric general circulation model, Geophys. Res. Lett., 25, 345-348, 1998.

Koster, R. D. and Suarez, M. J.: Relative contributions of land and ocean processes to precipitation variability, J. Geophys. Res., 100, 13775-13790, 1995.

Koster, R. D., Suarez, M. J., and Heiser, M.: Variance and predictability of precipitation at seasonal-to-interannual timescales, J. Hydrometeorol., 1, 26-46, doi:10.1175/1525-7541(2000) 001<0026:VAPOPA) 2.0.CO;2, 2000.

Koster, R. D., Dirmeyer, P. A., Hahmann, A. N., Ijpelaar, R., Tyahla, L., Cox, P., and Suarez, M. J.: Comparing the degree of land-atmosphere interaction in four atmospheric general circulation models, J. Hydrometeorol., 3, 363-375, doi: 10.1175/1525-7541(2002)003〈0363:CTDOLA〉2.0.CO;2, 2002.

Koster, R. D., Dirmeyer, P. A., Guo, Z., Bonan, G., Chan, E., Cox, P., Gordon, C. T., Kanae, S., Kowalczyk, E., Lawrence, D., Liu, P., Lu, C.-H., Malyshev, S., McAvaney, B., Mitchell, K., Mocko, D., Oki, T., Oleson, K., Pitman, A., Sud, Y. C., Taylor, C. M., Verseghy, D., Vasic, R., Xue, Y., and Yamada, T.: Regions of strong coupling between soil moisture and precipitation, Science, 305, 1138-1140, doi:10.1126/science.1100217, 2004.

Koven, C. D.: On the sources, composition, and climatic effects of mineral dust in the atmosphere, Ph.D. thesis, University of California at Berkeley, 2006.

Lee, J.-E., Oliveira, R. S., Dawson, T. E., and Fung, I.: Root functioning modifies seasonal climate, P. Natl. Acad. Sci. USA, 102, 17576-17581, doi:10.1073/pnas.0508785102, 2005. 
Li, H., Robock, A., and Wild, M.: Evaluation of Intergovernmental Panel on Climate Change Fourth Assessment soil moisture simulations for the second half of the twentieth century, J. Geophys. Res., 112, D06106, doi:10.1029/2006JD007455, 2007.

Liu, Y., Stanturf, J., , and Lu, H.: Modeling the potential of the northern China forest shelterbelt in improving hydroclimate conditions, J. Am. Water Resour. As., 44, 1176-1192, doi:10.1111/ j.1752-1688.2008.00240.x, 2008.

Luo, Y., Berbery, E. H., Mitchell, K. E., and Betts, A. K.: Relationships between land surface and near-surface atmospheric variables in the NCEP North American Regional Reanalysis, J. Hydrometeorol., 8, 1184-1203, 2007.

Matthews, E.: Global vegetation and land use: new highresolution data bases for climate studies, J. Appl. Meteorol., 23, 474-487, doi:10.1175/1520-0450(1983)022〈0474:GVALUN $\rangle 2$. $0 . \mathrm{CO} ; 2,1983$.

Maxwell, R. M., Chow, F. K., and Kollet, S. J.: The groundwaterland-surface-atmosphere connection: Soil moisture effects on the atmospheric boundary layer in fully-coupled simulations, Adv. Water Resour., 30, 2447-2466, doi:10.1016/j.advwatres. 2007.05.018, 2007.

Nepstad, D. C., de Carvalho, C. R., Davidson, E. A., Jipp, P. H., Lefebvre, P. A., Negreiros, G. H., da Silva, E. D., Stone, T. A., Trumbore, S. E., and Vieira, S.: The role of deep roots in the hydrological and carbon cycles of Amazonian forests and pastures, Nature, 372, 666-669, doi:10.1038/372666a0, 1994.

Niu, G.-Y., Yang, Z.-L., Dickinson, R. E., Gulden, L. E., and Su, H.: Development of a simple groundwater model for use in climate models and evaluation with Gravity Recovery and Climate Experiment data, J. Geophys. Res., 112, D07103, doi: 10.1029/2006JD007522, 2007.

Oliveira, R. S., Dawson, T. E., Burgess, S. S. O., and Nepstad, D. C.: Hydraulic redistribution in three Amazonian trees, Oecologia, 145, 354-363, doi:10.1007/s00442-005-0108-2, 2005.

Ornstein, L., Aleinov, I., and Rind, D.: Irrigated afforestation of the Sahara and Australian Outback to end global warming, Climatic Change, 97, 409-437, doi:10.1007/s10584-009-9626-y, 2009.

Ramankutty, N. and Foley, J. A.: Estimating historical changes in global land cover: croplands from 1700 to 1992, Global Biogeochem. Cy., 13, 997-1027, 1999.

Rayner, N. A., Parker, D. E., Horton, E. B., Folland, C. K., Alexander, L. V., Rowell, D. P., Kent, E. C., and Kaplan, A.: Global analyses of sea surface temperature, sea ice, and night marine air temperature since the late nineteenth century, J. Geophys. Res., 108, 4407, doi:10.1029/2002JD002670, 2003.

Reale, O. and Dirmeyer, P.: Modeling the effect of land surface evaporation variability on precipitation variability. Part I: general response, J. Hydrometeorol., 3, 433-450, doi:10.1175/ 1525-7541(2002)003〈0433:MTEOLS $\rangle 2.0 . C O ; 2,2002$.

Reale, O., Dirmeyer, P., and Schlosser, A.: Modeling the effect of land surface evaporation variability on precipitation variability. Part II: time- and space-scale structure, J. Hydrometeorol., 3, 451-466, doi:10.1175/1525-7541(2002)003〈0451:MTEOLS $\rangle$ 2.0.CO;2, 2002.

Richter, D. D. and Markowitz, D.: How deep is soil?, Bioscience, 45, 600-609, 1995

Rosenzweig, C. and Abramopoulos, F.: Land-surface model development for the GISS GCM, J. Climate, 10, 2040-2054, doi: 10.1175/1520-0442(1997)010〈2040:LSMDFT〉2.0.CO;2, 1997.
Schlosser, C. A. and Milly, P. C. D.: A model-based investigation of soil moisture predictability and associated climate predictability, J. Hydrometeorol., 3, 483-501, 2002.

Schmidt, G. A., Aleinov, I., Bell, N., Bauer, M., Bauer, S., Cairns, B., Faluvegi, G., Hu, Y., Kiang, N. Y., Koch, D., Lerner, J., Nazarenko, L., Perlwitz, J., Thresher, D., Ruedy, R., Cheng, Y., Lo, K. K., Oinas, V., Sato, M., Tausnev, N., Yao, M.-S., Hansen, J. E., Canuto, V., Genio, A. D., Hall, T. M., Lacis, A. A., Miller, R. L., Rind, D., Russell, G. L., Shindell, D. T., Friend, A. D., Kelley, M., Romanou, A., Perlwitz, J., and Stone, P. H.: Presentday atmospheric simulations using GISS ModelE: comparison to in situ, satellite, and reanalysis data, J. Climate, 19, 153-192, doi:10.1175/JCLI3612.1, 2006.

Schubert, S. D., Suarez, M. J., Pegion, P. J., Koster, R. D., and Bacmeister, J. T.: Causes of long-term drought in the U.S. Great Plains, J. Climate, 17, 485-503, doi:10.1175/1520-0442(2004) 017 $\langle 0485$ :COLDIT $\rangle$ 2.0.CO;2, 2004.

Shukla, J. and Mintz, Y.: Influence of land-surface evapotranspiration on the earth's climate, Science, 215, 1498-1501, doi: 10.1126/science.215.4539.1498, 1982.

Sobel, A. H., Nilsson, J., and Polvani, L. M.: The weak temperature gradient approximation and balanced tropical moisture waves, J. Atmos. Sci., 58, 3650-3665, doi:10.1175/1520-0469(2001) 058<3650:TWTGAA $>2.0 . C O ; 2,2001$.

Stone, E. L. and Kalisz, P. J.: On the maximum extent of tree roots, Forest Ecol. Manag., 46, 59-102, 1991.

Trenberth, K. E.: Atmospheric moisture residence times and cycling: implications for rainfall rates and climate change, Climatic Change, 39, 667-694, doi:10.1023/A:1005319109110, 1998.

Trenberth, K. E. and Guillemot, C. J.: Physical processes involved in the 1988 drought and 1993 floods in North America, J. Climate, 9, 1288-1298, doi:10.1175/1520-0442(1996)009<1288: PPIITD $>2.0 . C O ; 2,1996$.

Wei, J., Dickinson, R. E., and Chen, H.: A negative soil moistureprecipitation relationship and its causes, J. Hydrometeorol., 9, 1364-1376, doi:10.1175/2008JHM955.1, 2008.

Yang, F., Kumar, A., and Lau, K.-M.: Potential predictability of U.S. summer climate with "perfect" soil moisture, J. Hydrometeorol., 5, 883-895, doi:10.1175/1525-7541(2004)005<0883: PPOUSC $>2.0 . C O ; 2,2004$.

Zampieri, M., D'Andrea, F., Vautard, R., Ciais, P., de NobletDucoudré, N., and Yiou, P.: Hot European summers and the role of soil moisture in the propagation of Mediterranean drought, J. Climate, 22, 4747-4758, doi:10.1175/2009JCLI2568.1, 2009.

Zeng, N., Neelin, J. D., Lau, K.-M., and Tucker, C. J.: Enhancement of interdecadal climate variability in the Sahel by vegetation interaction, Science, 286, 1537-1540, doi:10.1126/science. 286.5444.1537, 1999

Zhang, J., Wang, W.-C., and Wei, J.: Assessing land-atmosphere coupling using soil moisture from the Global Land Data Assimilation System and observational precipitation, J. Geophys. Res., 113, D17119, doi:10.1029/2008JD009807, 2008.

Zhang, J., Wang, W.-C., and Wu, L.: Land-atmosphere coupling and diurnal temperature range over the contiguous United States, Geophys. Res. Lett., 36, L06706, doi:10.1029/2009GL037505, 2009. 